\section{THE METRIC SYSTEM OF WEIGHTS AND MEASURES.}

$A$ DEPUTATION representing forty-six Chambers of A Commerce, announced in these columns a fortnight ago, waited upon Mr. Balfour, First Lord of the Treasury, on November 20, to urge upon the Government the desirability of adopting the metric system of weights and measures, as recommended by the late Select Committee on the subject. It will be gratifying to men of science to know that the commercial world has been brought to support a reform advocated by them for many years. When the question was merely one of simplicity, little importance was attached to it, but now that commercial men have learned that our chaotic system of weights and measures is a serious obstacle to international trade, the matter is taken into the region of practical politics. On the whole, Mr. Balfour's reply to the deputation is satisfactory. The best way to the adoption of the metric system in this country is by educating the mass of the people in its use ; in other words, the transition will have to be gradual rather than an abrupt change brought about by legal process. By all means let the metric system be legalised, but it cannot be seriously believed that in two years people would submit to having the system thrust upon them by Act of Parliament. The Select Committee of the House of Commons recommended "That the metrical system of weights and measures be taught in all public elementary schools as a necessary and integral part of arithmetic, and that decimals be introduced at an earlier period of the school curriculum than it is at present." This recommendation ought certainly to be carried out, for when the use of decimals has become common, and the convenience of the metric units has become widely known, there will be little need for legislation to make the use of the system compulsory. But the question is not only one of ways and means; for if England adopts the metric system, then France will, in all probability, adopt Greenwich time, and there will then be one time system throughout the world.

The deputation to Mr. Balfour was introduced by Sir A. K. Rollit, M.P., who was supported in his remarks by Sir Henry Roscoe, Sir Samuel Montague, M.P., Mr. Arnold-Forster, M.P., and several other members.

Sir Henry Roscoe said: As Chairman of the Select Committee, the report of which has been referred to in the memorial, I desire, Mr. Balfour, to be allowed to say a few words on the question at issue, of which, I may add, it is difficult to overestimate the importance; and, in the first place, I wish to remark that the Committee consisted of seventeen Members of Parliament, chosen from both sides of the House, and that of these seventeen only one was opposed to the recommendations made by the majority and embodied in the report-i.e. that the metrical system of weights and measures should be at once rendered legal for all purposes of trade as well as for manufacture ; and that, further, within a space of two years, the metrical be adopted as the only legalised system. These recommendations were founded on the evidence given by thirty-two witnesses, representing very many different interests, and selected from persons of every class of the community. Of these only onei.e. Sir Frederick Bramwell-was in favour of retaining the present system, although he had no objection to the legalisation of the metrical weights and measures. With this single exception all the witnesses expressed/a very strong opinion as to the evil effects arising from the complicated and unsatisfactory condition of our present system of weights and measures. They called attention to the distinct and serious degree to which, in their opinion, our commerce-especially our foreign commerceis handicapped in consequence of the use of the present system, differing, as it does, from that now adopted by every European nation except ourselves and Russia, as well as by far the greater majority of the non-European countries with which this kingdom trades. Not only, however, was it proved to the satisfaction of the Committee that our foreign trade suffers greatly, but also that our home trade would be benefited by the adoption of a simpler and uniform system of weights and measures.

From the educational side, also, evidence showed the urgent need of an adoption of a simpler system, and it appears from the statements of experts that the school time now devoted to arith metic would be lessened by one year if a simpler system were substituted for the cumbrous one now in vogue, and thus our children placed on a par with those taught in foreign schools. This led to the second recommendation--viz. "That the metrical system be taught in all public elementary schools as a necessary and integral part of arithmetic, and that decimals be introduced at an earlier period of the school curriculum than is the case at present, and before vulgar fractions."

On inquiry, the Committee learnt that the compulsory changes from old and complicated to a new and simple system had been accomplished in Germany, in Norway and Sweden, in Switzerland, in Italy, in Bulgaria, in Japan, in Turkey, and even amongst the black population of French dependencies in Africa, without any difficulty in a comparatively short period of time, and without any opposition; that in every case the people in these countries are satisfied that the change has been for the better, and that in no single instance has an attempt been made to recur to the old system.

It has often been stated that this agitation for the adoption of the metrical system is got up by scientific men or faddists, who have no knowledge of the practical difficulties which will arise in the application of a new system to ordinary life. That this is not so is shown not only by the composition of the present deputation representing, as it does, so powerfully the com mercial interests of the Empire, but also by the statement emphasised in the evidence given before the Committee, that the working classes, at any rate the more intelligent of them, are interesting themselves in the matter and have passed very strong resolutions in favour of the change. Thus the Trade Union Congress held in Glasgow in September 1892 , at which 495 delegates were present, representing nearly a million and a quarter of members, passed the following resolution: "That in the opinion of this congress it is highly desirable in the interests of the working classes and of the general trade of the country that the decimal system (meaning the metrical system) of weights and measures shall be adopted in Great Britain and Ireland as a national system, and that a Parliamentary Committee be instructed to promote legislation on the question"; whilst a similar resolution was passed at the Belfast Congress in the following year, at which 380 delegates were present representing 900,000 members. A large number of other trade societies have sent in memorials in favour of the adoption of the metrical system ; amongst many others, the United Bargemen and Watermen's Protection Society, the Working Men's Club and Institute Union, the Trades Councils of Sheffield, Glasgow and Bolton, the National Union of Gas-workers, the Boot and Shoe Union of Leicester, the Manchester and Salford Trades Council, the Dockers Union, the Amalgamated Society of Railway Servants in Scotland, and the General Railway Workers Union.

Important evidence was obtained from manufacturers who have adopted the metrical system in their works; the most interesting of these is perhaps that of Captain Sankey, a director of the well-known firm of Willans and Robinson, engineers. This firm has adopted the metrical measurements, not only to their own advantage, but to the satisfaction and with the cordial co-operation of their workmen, some of whom are merely ordinary English labourers. A series of questions was drawn up by the firm, for the purpose of ascertaining how far the men were satisfied or otherwise with the change, and the answers to a number of searching questions showed that the men were not only satisfied but pleased, and had no wish to recur to the old measurements. An honourable member of the Committee asked this witness whether he had found that his men had any difficulty in adapting themselves almost immediately to the new system, and the answer was, "Not after the first few days." The witness added: "I asked that very question to the head of our tool-room, and he said it was a little awkward for a time. I said, 'About how long?' and he said 'Two days." "And in further examination this witness stated that the workmen knew nothing of the metrical system beforehand.

Another interesting witness was the Chairman of the Incorporated Society of Inspectors of Weights and Measures. He came forward as an expert in these matters, and he agreed that the metrical system ought to be made compulsory, and in expressing this opinion he spoke for his Society. He gave a long list of anomalous customary measures, which are now, although illegal, still in use

No. I 361 , VOL. 53.] 
in various parts of the country. He explained that it was difficult, under the present system, to prevent the use of these irregular weights, but that if a new unit or system were adopted, then it would be possible to put an end to the employment of these ridiculous so-called customary weights.

The Committee found it impossible to obtain any evidence either from manufacturers, from retail dealers, or, with the exception I have mentioned, from professional men, in opposition to the recommendations which they have made; and amongst the members of the Committee the one opponent of their recommendations was Mr. Stevenson, who added a report of his own, which is printed with the evidence, but which did not find a seconder. Reference was made to the fact that, in the Parliamentary Report of a Committee which sat thirty-three years ago on this subject, two very distinguished men of science-i.e. the late Astronomer Royal, Sir George Airy, and Sir John Herschel -expressed strong opinions in opposition to the adoption of the metrical system. One witness, Lord Kelvin, on being asked by the Chairman how far in his opinion that evidence applies at the present time, answered: "I believe these two great men would see things very differently now ; their minds had not been opened to the great advantages of the metrical system. Since they gave that evidence every country in Europe has accepted the metrical system except ourselves, and the general understanding of these subjects has certainly advanced very much"; and he went on to say that he did not think that at the present moment a Committee on the subject need consider the objections thus raised thirty years ago as being of importance; on the contrary, he would like to see the metrical system made compulsory after the lapse of a certain period, and would not be satisfied without a thorough adoption of this as the only legal system in the country. Moreover, he did not think decimalisation of the coinage was at all a necessary accompaniment for the adoption of the metrical system of weights and measures.

Further evidence went to show that in the United States the metrical system was actually legal, was in use within the State of Utah, and has been adopted as a compulsory system for all pharmaceutical and medical purposes; that this latter also is the case in Russia ; and quite recently the announcement has been made that in the new edition of the "British Pharmacopceia," about to be issued, the metrical weights and measures will be adopted. It appeared to be a general opinion amongst witnesses consulted by the Committee that it only requires that England should take the initiative, in order that both Russia and the United States-the only civilised countries now not using the system-should at once adopt it, and thus all nations would have one and the same system, and that this would be an incalculable benefit to mankind.

Mr. Balfour is reported by the Times to have replied as follows : "I have listened with very great interest to the powerful speeches that have been made upon the important subject with regard to which we are met here to-day. If I may express my own opinion upon the merits of the case, there can be no doubt I think whatever that the judgment of the whole civilised world, not excluding the countries which still adhere to the antiquated systems under which we suffer, has long decided that the metric system is the only rational system. Scientific men in this country have long been driven to use it in their writings, to use it in their calculations, and, if I may so express it, to think in it, to think out the problems in which they deal in the system which we owe to the ingenuity of the French. What men of science have long been obliged to do-not merely because the international character of science makes it desirable, but also because the calculations are so much more rapid, so much more convenient-what men of science for those reasons are obliged to do, I believe that commercial firms in all parts of the country are beginning to think they must do also. On that point I do not think that argument is possible. The solitary argument which appears to have been alleged on the other side is that the existing English system is a good gymnastic for the mind. I dare say it would be a very good gymnastic for the body if, instead of having macadamised roads, we were obliged to make our way over pathless heaths and plunge through ditches and over hedges; but though it would be an excellent gymnastic for the body it would not be a convenient method of getting from place to place, and I do not think any one is likely to recommend that we should return to the primitive kinds of locomotion once used by our forefathers. There appears, therefore, to be an absolute agreement on the merits of the case. There is no such agreement with regard to the practicability or the ease of carrying out any great change. We in this country are rather in the condition of an industrial concern which was using antiquated plant, but which felt that it could not renew that plant according to modern requirements without an immense expenditure of capital which for some years would destroy all the profits, or a large part of the profits, of the undertaking. In precisely the same way, while everybody admits that the change when once effected would be a change of almost universal beneficence, I think we ought not to conceal from ourselves that there would be loss and inconvenience during the period of transition. I think we have only got to consider our own personal experience to see that that is so. Like the rest of the world, I have had to read books in which the metric system was the one in use. As I have been brought up on the English system, there has always been a certain difficulty in representing to the imagination without effort and immediately by an automatic process exactly what was intended. To translate miles into kilometres is not a very difficult process, but it is not automatic even to the person who knows the exact length of the kilometre and mile. And what is difficult to us who have been to a certain extent habituated to both systems, would certainly be difficult to the great mass of retail traders and the great body of the poor. They have been accustomed to think in one kind of measure, and to require them by law suddenly to think in another kind is to compel them to go through an effort which I think every one will admit would be an arduous effort in some cases, and an effort which would not be unaccompanied by mistakes and difficulties on the part of those who are unaccustomed to it. It is a matter, it will be observed, largely of familiarity and imagination. We all know what we mean by a yard. To translate that into a metre requires a little effort. We all know what we mean by a mile, to represent it in the imagination, but to translate it into a kilometre requires an effort, and I do not think we should underrate the obstacles in carrying out the beneficent change. I was struck by what fell from Sir Henry Roscoe and some other members of the deputation with regard to the extraordinary vitality in England of antiquated and illegal weights and measures in different parts of the country. Although our existing measures are the only legal ones, it appears that other measures are in habitual use by large portions of the population. If old measures are so difficult to kill, as they clearly are, we must not forget that we have a very heavy task before us to bring about the great change of the existing system to the decimal system. I have been informed that in France, where the metric system has now long been in use, where it is universally believed in as the only rational system, I believe that even in France, in some parts, the population prefer some of the old measures which their fathers were accustomed to rather than the rational system which has now for more than two generations been the only legal one in force. Therefore we ought not to approach the solution of this problem in too sanguine a spirit. I observe that there are three recommendations which the Chambers of Commerce have formulated and embodied in the memorial presented to me to-day. The first is that the metrical system of weights and measures should at once be legalised for all purposes. The second is that it should be the only legal system allowed in this country after two years. The third is that every effort should be made to teach it in the elementary schools. With the first and third of these I find myself in entire agreement. I am told that there are legal obstacles to the use in all trades, and I am quite unable to see why that obstacle should be continued. I think it is our business to do everything we can to smooth the transition from the old to the new system, and certainly the first step towards smoothing that transition would be to make legal that which we think desirable and which we may ultimately think necessary. I was struck by an observation from Mr. Arnold-Forster in regard to the standing orders of the House of Commons, and to the exclusion of the metric system from our national manufactures-that is, manufactures undertaken by the Government. I think both of those are topics well worthy of consideration, and I shall consult with my friend Mr. Ritchie and the other departments of the Government concerned to see whether from either of those points of view anything can be done to meet the general wishes of the commercial classes as represented by the Chambers of Commerce. With regard to the teaching of the metric system in elementary schools, I believe something has been done already in that direction by the Education Department, but on that topic also I shall consult

NO. I 36.1, VOL. 5.3] 
Sir John Gorst and see whether we cannot do something to spur on the teaching of the metric system in the schools, and thereby familiarising the imagination of the rising generation to a system which perhaps ultimately will be the only one they will be permitted to use. With regard, however, to the second proposition in the order of statement by the Chambers of Commerce, you will have gathered from what I have said that I should see very great difficulties in compelling every class in the community suddenly to alter its familiar and habitual practice in regard to the weights and measures in which it deals. If I may venture to say so, I hardly think that the Chambers of Commerce, or even the trade union congresses, are adequate representatives of the kind of feeling which would probably animate the great mass of small retail clealers and those who buy their goods from such dealers, who would suddenly find all their familiar landmarks swept away and unfamiliar things put in their places. You represent the great commercial interests of the country, and possibly you might find a degree of opposition to your proposals which you little anticipated if you were to endeavour to drive into every cranny of our social system changes which no doubt would be very beneficial as applied to the great industries and manufactures. That leads me to ask -if the advantages of the metric system as compared with the existing system be so great as you tell me they are, as I fully believe they are--whether they could not now be adopted, for instance, in shipbuilding yards on the Clyde, in the great machine-making industries of Manchester, and in such commercial centres as Belfast. I think one gentleman did mention a firm which had employed it, and which had no difficulty in employing it. The engineers do it now, and they have not found much difficulty in doing it, and they have derived much benefit from it. Surely it is within the province of private enterprise to extend that system to every one of the great industries which bring us into relation with foreign countries. The foreign meat trade is already largely carried on on a decimal system, but not the metric. What I want to insist upon is that, while it is of great importance to render such a change easy, it is within the province of private enterprise to carry it out gradually in those great industries. I cannot but believe that if you represent, as $1 \mathrm{am}$ sure you do, the feeling of the great industries in this matter, we shall find, without any compulsion on the part of the Government at all, the metric system making its way through all the leading industries. It must be legalised certainly, but, when legalised, it will make its way. It is evident that, in so far as that process is carried on, you would enormously facilitate that ultimate compulsory change to which we all look forward, but which, I think, could not, with safety or advantage, be undertaken by the Government till public opinion is more prepared for it than at present. The public opinion with which we have got to deal, and which we are bound to consider, is not the public opinion of the great manufacturers alone, but the public opinion of every man and woman you meet in the street. While I look forward to the time, and no distant time, when they will adopt the change without difficulty and without repugnance, I should like to see private enterprise do more than it has done up to the present to show that the change can be adopted without inconvenience, and that it carries with it all the benefits which $I$, in common with you, firmly believe to be attached to the metric system, and which it is impossible to associate with the arbitrary, perverse, and utterly irrational system under which we have all had the misfortune to grow up."

\section{NOTES.}

A LARGE and influential deputation is to wait on the Duke of Deronshire at noon to-day to urge on the Government the importance of introducing, at an early date, a Bill appointing a Statutory Commission to give effect to the recommendations of the late Royal Commission on the London University question.

THE first meeting of the General Committee of the Huxley Memorial was held, under the presidency of the Duke of Devonshire, yesterday, as we went to press. The chief object of the meeting was to decide the form which the memorial should take. The long list of the General Committee, consisting of the names of men of light and leading in all parts of the world, is a striking testimony to Huxley's greatness.

$$
\text { NO. I } 36 \text {, VOL. } 53]
$$

THE Egyptian Crovernment have determined to commence a geological survey of the "land of Egypt." The work will be begun next year, and will take about three years for its com. pletion, the estimated cost being $£ 25,000$. To carry out the proposed plans, a wise selection of a geologist has been made in the person of Captain H. G. Lyons, R.E., who is at present engaged (under the Public Works Department of the Egyptian Government) in superintending the excavation of the ruined temples of Philæ. Captain Lyons has already written an excellent article on the "Stratigraphy and Physiography of the Libyan Desert of Egypt" in the Geological Society's Fournal for 1894 , and has also made extensive explorations on the Upper Nile. Had the Egyptian Government taken this step some years ago, they might have saved some considerable sums of money which they have squandered in searches for petroleum and various minerals, undertaken at the instigation of inexperienced and interested advisers.

A SHARP earthquake shock occurred at Athens at 7.30 on Wednesday morning, and was also felt at Chalcis, Livadia, Thebes, and Corinth.

DR. J. D. Cillchrist has been appointed Marine Biologist to the Government of the Cape of Good Hope. He will be charged with the investigation of the marine resources of the country, especially in their practical relations to the fisheries.

A Commitree has been formed to make arrangements for presenting to Prof. Adolf Bastian, Professor of Ethnology in Berlin, a volume of original essays on various branches of ethnology, anthropology, and kindred sciences, when he attains his. seventieth birthday in June next.

We learn from the Lancet, that the Health Committee of the Glasgow Town Council has decided to establish and equip a complete bacteriological department in the sanitary buildings now in course of erection. The laboratory is to be in charge of an expert in bacteriology.

THE British Medical Fournal states that Prof. Loeffler, of Greifswald, the discoverer of the diphtheria bacillus, has received from the French Government the Officer's Cross of the Legion of Honour.

DR. CARTWRIGHT Woov has been granted $£$ IOo out of the Goldsmiths' Company's grant allocated by the Committee of the Conjoint Laboratories of the Royal Colleges of Physicians and Surgeons, for investigations as to improved means of treating horses with a view to obtaining diphtheria antitoxic serum in a shorter time than is possible by the methods hitherto in use.

OUR contemporary Invention has lately been brought out in a popular penny series. We hope and believe that in this form it will play a useful part by showing to a wide circle of readers some of the work that has been, and is being, done in the world of science, and by indicating how intimately scientific research is connected with industrial progress.

WE notice with regret the death of Mr. J. Traill Taylor, editor of the British Foumal of Photography. He was in his sixty-ninth year, and was widely known and respected in photo. graphic circles. We have also to record the death of Prof. George Lawson, Professor of Chemistry and Mineralogy in the University of Halifax, Nova Scotia, and formerly President of the Royal Society of Canada.

THE death is announced of Surgeon-Major Cieorge Edward Dobson, F.R.S., at the age of forty-seven. He was awarded the gold medal of the Dublin Pathological Society in 1867 for his essay on the diagnosis and pathology of the injuries and diseases of the shoulder-joint. He also wrote "Medical Hints to Travellers," putblished by the Royal Geographical Society; 